\title{
THE PROCESS OF THE SPATIAL DEVELOPMENT OF LARGE CITIES IN POLAND AND ITS ADAPTATION TO CLIMATE CHANGE: OPPORTUNITIES AND THREATS
}

\author{
Bożena Degórska, Marek Degórski \\ Institute of Geography and Spatial Organization \\ Polish Academy of Sciences \\ Twarda 51/55, 00-818 Warsaw, Poland \\ bodego@twarda.pan.pl,m.degor@twarda.pan.pl
}

\begin{abstract}
This article draws attention to key aspects of the dynamic relationship between urbanisation and climatic conditioning, with particular account taken of the ventilating and cooling of cities and the influence of ecological continuity and connectivity between urban and open areas. Such phenomena are discussed in the context of the quality of life enjoyed by inhabitants of urbanised areas. The role of green infrastructure in shaping urban space from the point of view of the easing or amelioration of negative thermal phenomena is discussed, as is the influence of climatic conditions on the functioning of cities' water systems. Reference is also made to demographic change in cities, given the major influence this has on inhabitants' vulnerability to the negative impacts of developing heat islands, most especially in periods of severe and/or prolonged heatwaves.
\end{abstract}

Keywords: climate change, adaptation, urban area, Poland.

\section{Introduction}

Obtaining the best possible conditions for human existence is a fundamental operational duty arising out of the assumptions underlying the sustainable development concept. As the object of the system of the geographical environment, the human being has an indisputable right to live in optimal existential conditions shaped through the interactions of interdependent processes and phenomena of a natural, social or economic nature. However, it does not always prove possible to achieve a harmonious state not disturbed by factors external to the functioning of the geographical environment megasystem, which would be characterised by a balanced flow of matter and energy in and between different (natural and anthropogenic) subsystems. For the potentially-existing equilibrium of this kind is in fact found to be disturbed regularly by exogenous and endogenous natural factors conditioning its functioning, as well as factors of an anthropogenic character. 
Global temperature increase is one of the direct causes of distortions of this kind observable in recent years when it comes to the functioning of the megasystem of the geographical environment. Notwithstanding some protracted debate as to the causes of climate change and predicted trends therefor, in regard to this and subsequent centuries, it is an incontestable fact that global average temperature is up by $0.76^{\circ} \mathrm{C}$ on the 1850 level, with this effect being non-synchronous, given that more than half of the rise has been accounted for by just the three most recent decades of history (IPCC 2007). The time since 1976 has thus brought abrupt increase globally, amounting to a $0.18^{\circ} \mathrm{C}$ rise for each 10-year period, and also with 13 of the 15 years in the 1995-2010 period being entries on the list of hottest years since 1850 (WMO 2013, IPCC 2007). However, the increase averaged for the Earth as a whole is found to be subject to marked variation from region to region. For example, in Central Europe, the period since 1950 has been associated with a statistically significant upward trend for maximum temperatures, as well as a steady rise from year to year in the number of days that are warm (with $\mathrm{T}_{\max } \geq 25^{\circ} \mathrm{C}$ ), hot $\left(\mathrm{T}_{\max } \geq 30^{\circ} \mathrm{C}\right)$ or very hot $\left(\mathrm{T}_{\max } \geq 35^{\circ} \mathrm{C}\right) .2015$ offered a further example of these trends.

In the face of these changes a matter of key importance from the societal point of view is the functioning of areas and environments characterised by the highest densities of population and shaped structurally and spatially to an extreme degree by human activity, i.e. towns and cities. Frequently, there is overpopulation - pure and simple - in these areas, with densities even in excess of 20,000 inhabitants per $\mathrm{km}^{2}$, as for example in Monaco. In such areas there are large numbers of buildings in very limited areas, as well as technical infrastructure; and hence a specific topoclimate that is seen to differ from that of open areas - not least in terms of spatial breakdowns for air temperature, precipitation totals and wind strengths. On the other hand, there remain many local natural factors capable of shaping the climate of an urban area, such as relief and land cover, the presence or absence of bodies of water, the extent of the remaining biologically active land surface, and so on. The climate of a town or city is also influenced by elements associated with human activity, first and foremost the two main sectors of the economy termed industry and transport, which are both very much concentrated in urban areas and feed the air with huge quantities of pollutants of many different kinds.

A consequence of air pollution is the appearance of phenomena that are at once ecologically and economically harmful and damaging to human health, such as smog, acid precipitation, and above all events entailing the stagnation of hot air in the summer period. Together these serve to increase the mortality rates noted for city-dwellers during heatwaves, most especially where people are already suffering from cardiological complaints. This process has now assumed statistically significant dimensions in such Polish cities as Warsaw (Kuchcik \& Degórski 2009). In line with models of the behaviour of climate in Europe (Greiving 2011), as well as forecasts to the year 2100 for the increased incidence of "tropical" nights (during which the temperature fails to fall below $20^{\circ} \mathrm{C}$ ) and very hot days (on which the air temperature exceeds $35^{\circ} \mathrm{C}$ ) (Fischer $\&$ Schar 2010), it can be anticipated that the incidence of events of this kind is set to increase steadily.

The aim of this paper is to present the most significant threats to the functioning of cities ascribable to changing climatic conditions, as well as the adaptive actions that will be essential if cities are to be prepared for ongoing phenomena and climatic processes. The analysis offered here pays particular attention to major issues attendant upon the dynamic relationship between urbanisation and climate change, with special account being taken of the ventilation and cooling of urban areas, the influence - for quality of life in cities - of ecological continuity and connectivity between urban and open areas, the role of green infrastructure in shaping urban space through the amelioration of negative effects, and the influence climatic conditions exert upon water systems in cities. 


\section{The development of cities and their sensitivity to climate change}

The process of urbanisation ongoing in the last 200 years is one of the causes of a rapid increase in the number of town- and city-dwellers that the so-called "demographic urbanisation" entails. As the $19^{\text {th }}$ century began, just $2.4 \%$ of the world's population was resident in towns and cities, but by 2007, the United Nations was beginning to maintain that more people were living in urban than rural areas, for the first time in history. The same UN (2007) reporting anticipated that $60 \%$ of humanity would be living in towns and cities by 2030. Inevitably, such an increase in numbers of people has been associated with increased sizes of urban areas (the so-called "spatial urbanisation"), with the process often assuming the uncontrolled features of what has become known as "urban sprawl" (Degórska 2007).

Different regions of the world are found to differ markedly in the above respect. In states enjoying only a limited level of economic and social development, those choosing to migrate to cities count on improved conditions for existence, but in fact themselves give rise to a process of over-urbanisation, in that they live - at least initially - in districts whose features do not allow for a categorisation as truly urban, given the way they fail to meet many of the functional conditions necessary for a city. Such circumstances of overcrowding in the face of poorly developed technical and social infrastructure - as well as green infrastructure - constitute such a huge functional and spatial problem because of the impacts they exert on quality of life in the affected communities, as well as these people's security, not least as regards health, and the capacity to adjust to climate change. These are the same kinds of reasons for cities in the developed world to spare no effort in making cities liveable, citizen-friendly and capable of engendering a sense of safety and comfort.

Poland is at present characterised by an index for demographic urbanisation at around $60 \%$ (59.6\% according to the last Census), though the trend has been downward - with a fall of around 3\% from the peak noted at the end of the $20^{\text {th }}$ century. In line with the urbanisation indicator used by the UN, Poland is among states with a medium or high level of urbanisation (the limit value distinguishing the categories being at $60 \%$ ). It nevertheless needs to be noted how the phenomenon of urbanisation is proceeding at varying intensities across Poland. There are regions that have been characterised by relatively strong processes of urbanisation for many years now, and in which the index of urbanisation rises by between 1 and $10 \%$. To be mentioned among these areas is the Tri-City, or specifically the Gdańsk Metropolitan Area plus areas along the Baltic coast between Gdynia and Władysławowo; the Bydgoszcz-Toruń Metropolitan Area; the areas of the Szczeccin, Poznań, Wrocław, Tarnów and Chełm agglomerations; as well as the northern, western and southern ring around Warsaw (Fig. 1). The counterweight for these trends is provided by areas undergoing depopulation. A large efflux of population is to be noted, not only in rural areas, but also in small towns - especially in eastern Poland; as well as in certain large agglomerations like that of Łódź. 


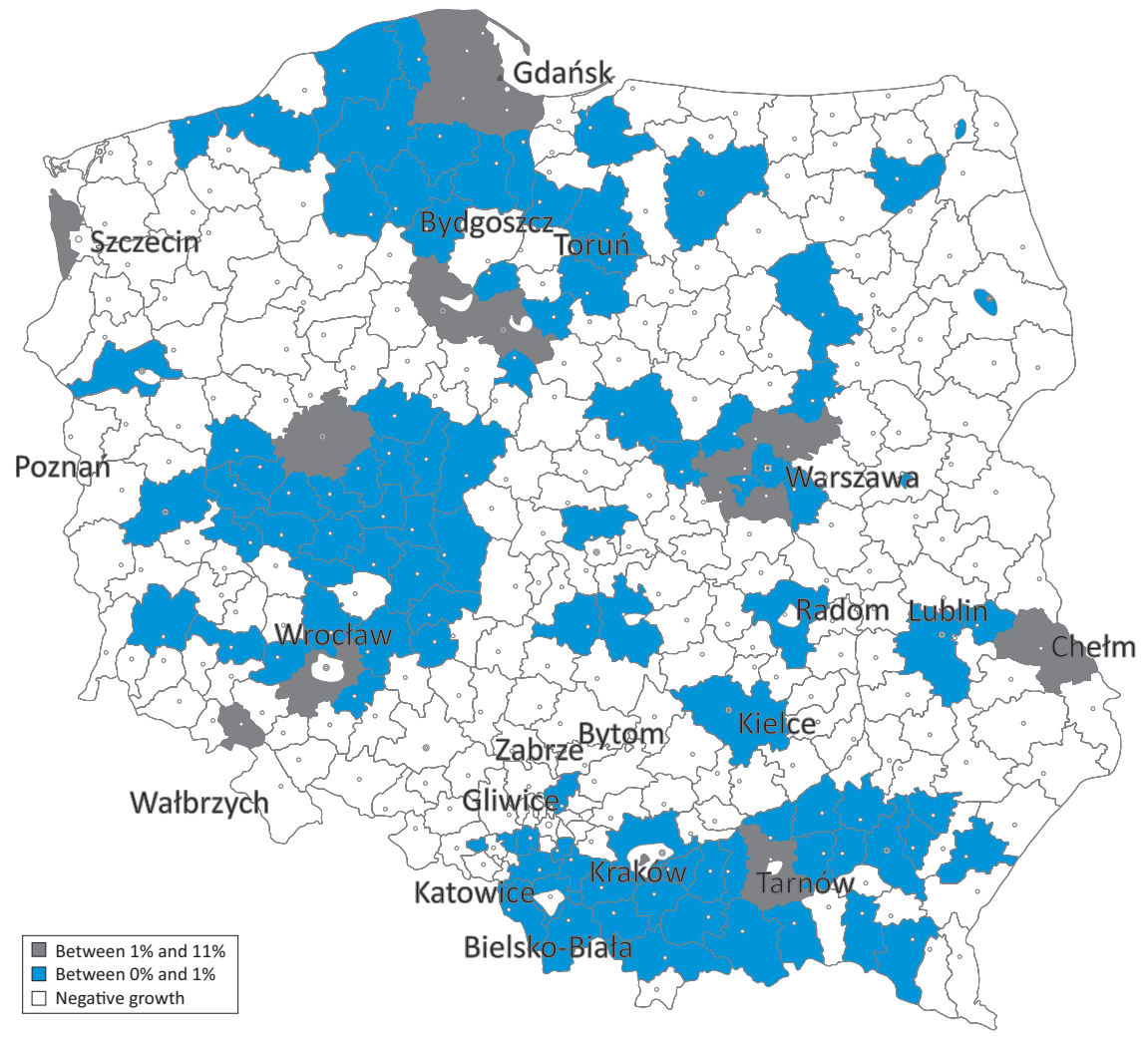

Figure 1. Population changes in Poland in the 1998-2008 period, as depicted at the county level, with areas in black subject to intensive urbanisation.

Source: the Polska 2011, Economy-Society-Regions Report from the Ministry of Regional Development.

The presented geographical trends for the development of urbanisation in Poland gain further confirmation if attention is paid to the distribution and scale of the phenomenon whereby agricultural and forest land is removed from these designated categories in order to allow for housing construction. At the beginning of this decade, it was in the voivodship (or province-region) of Pomorskie that the overall size of such excluded areas was greatest (363 ha), with the Śląskie, Zachodniopomorskie and Wielkopolskie voivodships taking the next places in the ranking (Tab. 1). 
Table 1. Exclusions from designation as agricultural and forest land for the purpose of housing construction in 2013

\begin{tabular}{|c|c|c|c|}
\hline \multirow{2}{*}{$\begin{array}{c}\text { Voivodship } \\
\text { (Province-region) }\end{array}$} & Overall & Agricultural & Forest \\
\hline & \multicolumn{3}{|c|}{ ha } \\
\hline Dolnośląskie & 57 & 57 & 0 \\
\hline Kujawsko-pomorskie & 31 & 27 & 5 \\
\hline Lubelskie & 70 & 46 & 1 \\
\hline Lubuskie & 56 & 72 & 0 \\
\hline Łódzkie & 102 & 49 & 6 \\
\hline Małopolskie & 130 & 114 & 1 \\
\hline Mazowieckie & 108 & 68 & 8 \\
\hline Opolskie & 9 & 7 & 0 \\
\hline Podkarpackie & 69 & 58 & 0 \\
\hline Podlaskie & 33 & 26 & 1 \\
\hline Pomorskie & 369 & 149 & 1 \\
\hline Śląskie & 183 & 66 & 3 \\
\hline Świętokrzyskie & 29 & 23 & 1 \\
\hline Warmińsko-mazurskie & 45 & 34 & 0 \\
\hline Wielkopolskie & 173 & 57 & 2 \\
\hline Zachodniopomorskie & 173 & 60 & 1 \\
\hline
\end{tabular}

Source: Authors' own elaboration on the basis of data from the Central Statistical Office (GUS) 2014.

The total for the number of towns and cities in Poland stands currently (as of early 2015) at 915. Among these localities, there are just 7 cities with more than 400,000 inhabitants, as well as 40 with more than 100,000 . This leaves the great majority of urban areas, which are effectively small or even very small towns of 10,000 inhabitants or less. Indeed, there are 109 "towns" with less than 2500 inhabitants each. In such localities, the issue of climate change is hardly tangible to inhabitants at all.

Equally, the vulnerability of urban areas to the negative consequences of climate change is greater where the process of spatial urbanisation is or has been intensive, and this is most particularly true of Poland's agglomerations and metropolitan areas. A very common result of urban spread or sprawl - everywhere in the world - is building in areas at risk of flooding, or else in remaining areas of greenery in the suburbs and on housing estates. Urban green space serves aesthetic functions, but also favours stabilisation of the heat balance. Its removal mostly leads to a sealing-off of soil under concrete and asphalt, with the effect that water retention is reduced and runoff enhanced. This compounds problems with the draining of wetlands for building, as well as the deliberate filling in of small ponds, and the canalisation and even burial of natural water courses. Then there is also the huge pressure urbanisation exerts on open areas that can only contribute to the system ventilating a city for as long as they remain free of buildings.

Where "natural" - or at least open - areas become more and more limited in relation to the overall settled area, the natural potential for a city to be cooled is more and more impaired. Increased density of construction and the introduction of taller buildings (and hence a larger amount of vertical surface) than hitherto into suburban zones encourages absorption of the Sun's rays, reduces wind speeds and helps to give rise to canyon effects. The result is enhancement of the urban heat island (UHI). Beyond 
that, temperature increase is actively magnified in city centres by heating and ventilation systems serving as additional anthropogenic sources of heat pollution, as well as by the physical properties of the materials most often covering urban land (i.e. concrete and asphalt), which are known to absorb more solar radiation than they reflect (EEA 2012).

Unfortunately, trends for change in the spatial structure of towns and cities are likely to be largely negative in character, where the quality of life of inhabitants is concerned. The pressure to build on and develop urban areas will continue to ensure the loss of biologically active surfaces and green infrastructure, with this process likely to prove a very intensive one in Poland's largest cities in particular. For example, among the least favourable forecast changes for Warsaw's green infrastructure through to the year 2070 is a loss of forest land and land planted with trees or shrubs from $17 \%$ to $14 \%$ of the city area - if the loss is mainly among the latter rather than the former, or even to $14 \%$ if forest is also subject to more major loss.

Furthermore, while private land under trees can be expected to be the first to lose this status unless the legal conditioning is changed, the pressure to build may even encourage inroads into the capital city's large, Treasury-owned complexes of woodland or forest. At present, even land falling within the Mazowiecki Landscape Park is being encroached upon, while some of the anticipated losses of forest area will link up with the construction of road (including motorway) infrastructure that is already anticipated. The plans in question indeed foresee a further bisection of forest complexes in the aforementioned area enjoying Landscape Park designation.

Equally serious will be the major loss of open green areas that currently allow cleaner, fresher air to flow into Warsaw's urbanised core. It is already expected that, beyond ongoing redevelopment of parts of the city-centre area, Warsaw urbanisation will mainly take place on what remains farmland at the present time. The assessment is thus that the share of open land within the city limits of Warsaw (taken to include farmland) will decline markedly from around $50 \%$ now to just some $35-37 \%$, with the main losses involved being of arable land.

All of these changes will undoubtedly lead to further areal expansion of the urban heat island, which has already enlarged greatly and become more persistent in the city area. According to K. Błażejczyk et al. (2014), it was present on almost $87 \%$ of days in a year throughout the 1981-2011 period, with the range being between $80 \%$ of winter days and $94 \%$ of those in the summer period.

The urban heat island proves particularly dangerous for the elderly, as frequent sufferers from vascular and cardiac disease and/or respiratory insufficiency. This is thus a population particularly prone to thermal stress, whose size is increasingly steadily. Ever-better and more accessible medical care ensures greater longevity of life, and there is a consequent increase in the proportions of the populations of urban agglomerations accounted for by the elderly. In order to determine the vulnerability of large cities associated with exposure to high temperatures, use is made of two measures:

- the absolute demographic heat-related health risk of a given city (ADHR), defined by the number of inhabitants aged up to 4 inclusive, as well as 65 or over,

- the demographic heat-related health risk $(D H R)$ - defined by the share of all inhabitants in the given city that are aged up to 4 inclusive, as well as 65 or over.

Among the Polish cities, it is Warsaw that faces the worst demographic situation, given that it has the highest concentration of inhabitants exposed to an absolute heat-related health risk, i.e. no fewer than 405,100 people, of which 223,500 are aged 75 and over. Further cities are Łódź, Kraków, Wrocław, Poznań and Gdańsk (Fig. 2 ). When it comes to the overall numbers of inhabitants facing risk as measured by the DHR index, residents of Warsaw are seen to account for $17.4 \%$ of the total (Fig. 3 ). 


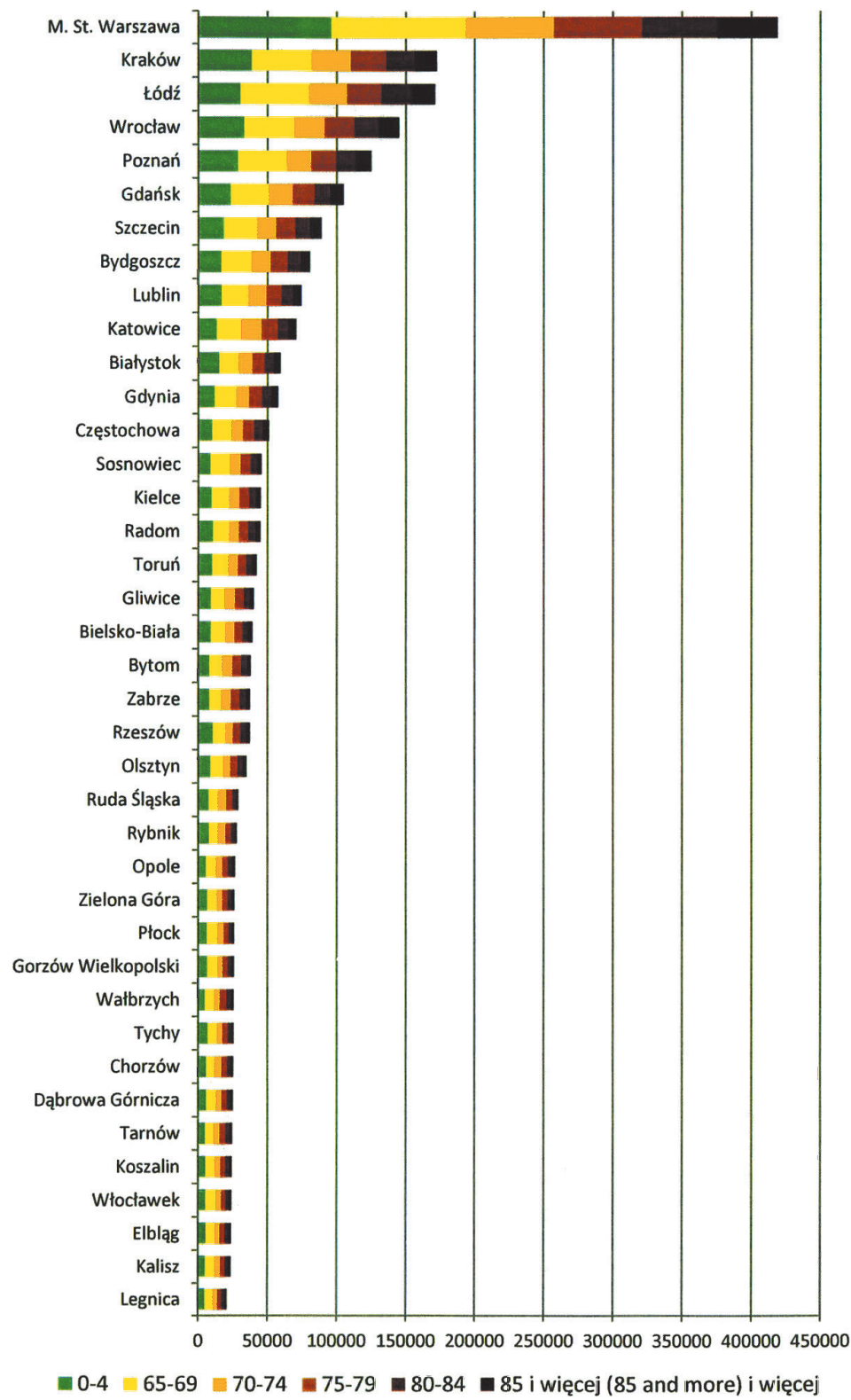

Figure 2. The absolute demographic heat-related health risk (ADHR) in cities of over 100,000 inhabitants (as of December 31st 2015)

Comparative analysis of large cities from the point of view of the DHR index shows that the largest proportion of the population of a given city facing a heat-related health risk is that to be noted in Warsaw, as followed by Łódź, Katowice, Chorzów and Gdynia. However, it is important to realise that cities differ rather little in terms of values for these indicators - being in the range $18.3 \%$ in Elbląg up to $23.6 \%$ in Warsaw (Fig. 3). 


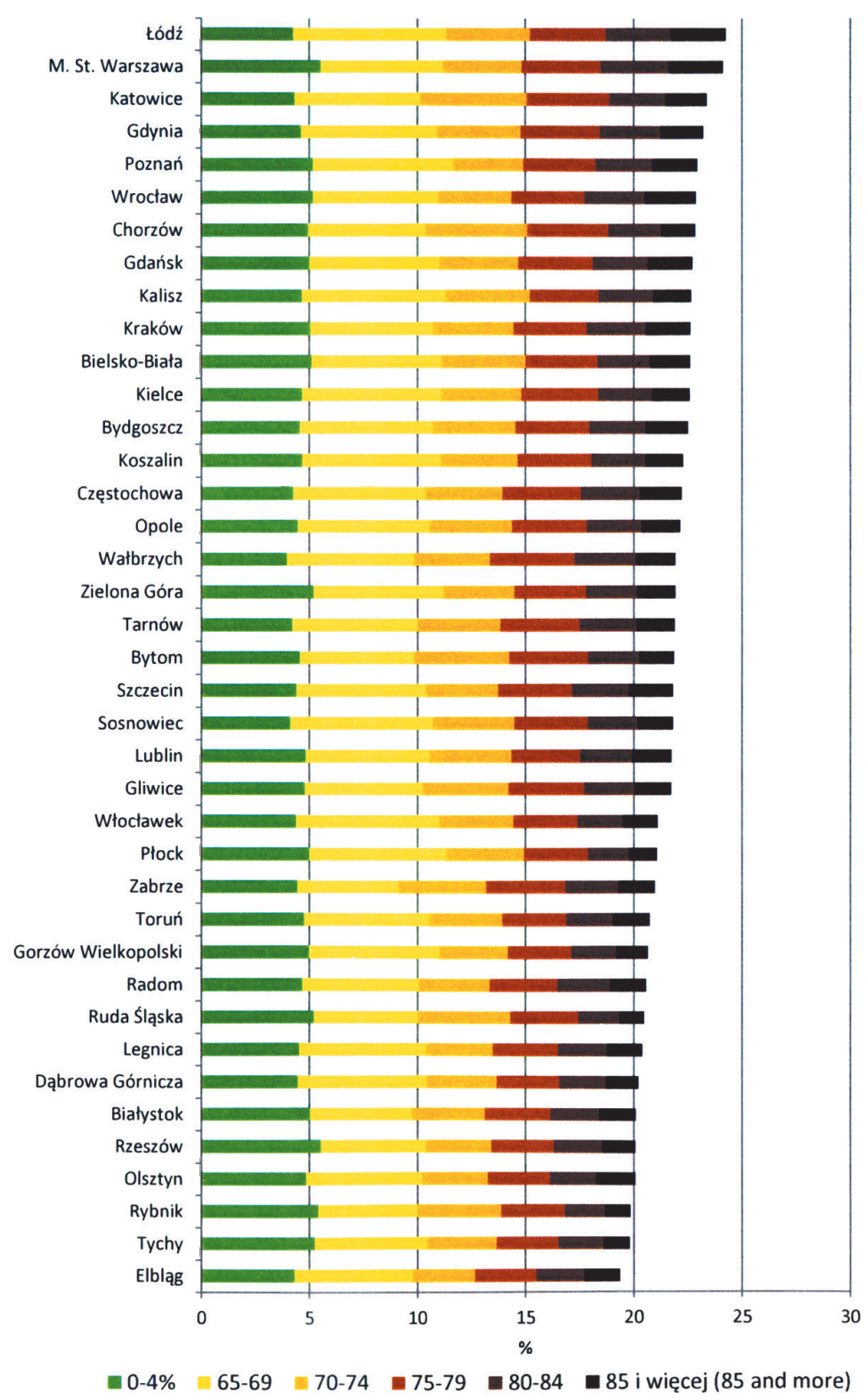

Figure 3. The demographic heat-related health risk (DHR) in cities of over 100,000 inhabitants (as of December 31st 2015)

In Polish conditions, ongoing development of urban areas is tantamount to an increase in the level of air pollution due to transport. On account of severe infrastructural under-development and the low quality of the service offered by public transport, commutes to work are mainly based around private cars, whose increasing numbers cause pollution, especially in city-centre areas, and along main arteries into and out of cities, where daily congestion makes matters still worse. The transport corridors running across Poland's cities are often also urban canyons tending to retain pollution. 
There are also certain Old Town areas of city centres in which household stoves continue to provide heating. Pollutants are also released to the atmosphere by large numbers of local boilerhouses, as well as by the heavy industry still associated with almost every urban agglomeration.

Alongside the direct health influences of pollutants - especially the oxides of nitrogen referred to as an indicator of transport-induced pollution, there is also the phenomenon of methane and volatile organic compound (VOC) release from sources like landfill sites (especially on hot summer days). Taken together, these pose a still-greater risk to health, thanks to the likelihood that ground-level ozone will be generated photochemically. Forecast climate warming will make this factor still more serious, but as of now it already seems to be more and more of a problem, often unfortunately being associated with urban areas where the traffic is heavy and there is a high concentration of industry. Table 2 presents gaseous emissions from industrial plants imposing particular burdens on the environment, including those of the oxides of nitrogen that are precursors of ozone pollution. The same compilation gives the numbers of days in which permitted levels of ozone are exceeded in cities with more than 100,000 inhabitants, in which monitoring for this pollutant is carried out. The number of such days per year is already seen to be at the level of 18 in the cases of Częstochowa and Dąbrowa Górnicza, and 16 in the case of Warsaw (Tab. 2). This of course denotes that, for more than half a month in each year, inhabitants of the cities in question are exposed to the impact of toxic ground-level ozone.

Table 2. Cities of more than 100,000 inhabitants with high environmental threat of air pollutants emission from plants especially noxious, as well as the numbers of days on which permitted concentrations of ozone are exceeded there

\begin{tabular}{|c|c|c|c|c|c|c|c|}
\hline \multirow{4}{*}{ City } & \multicolumn{5}{|c|}{ Emission of gaseous pollution } & \multirow{3}{*}{\multicolumn{2}{|c|}{$\begin{array}{l}\text { Number of days with } \\
\text { exceeded target value } \\
\text { of ozone concentration }\end{array}$}} \\
\hline & \multicolumn{2}{|c|}{ total } & \multirow{2}{*}{$\begin{array}{l}\text { sulphur } \\
\text { dioxide }\end{array}$} & \multirow{2}{*}{$\begin{array}{l}\text { nitrogen } \\
\text { oxide }\end{array}$} & \multirow{2}{*}{$\begin{array}{l}\text { carbon } \\
\text { dioxide }\end{array}$} & & \\
\hline & 2010 & 2014 & & & & & \\
\hline & & & thousan & ones & & 2010 & 2014 \\
\hline Warszawa & 6721,2 & 5765,0 & 13,4 & 6,8 & 5740.3 & 16 & 6 \\
\hline Białystok & 824,9 & 909,3 & 0,9 & 1,3 & 906,4 & 8 & 11 \\
\hline Bydgoszcz & 1208,9 & 824,5 & 4,0 & 1,9 & 817.9 & 0 & 7 \\
\hline Chorzów & 988,6 & 1452,1 & 1,7 & 1,1 & 1447,6 & 18 & n.d. \\
\hline Częstochowa & 742,7 & 829,1 & 1,1 & 2,1 & 824,4 & 18 & 15 \\
\hline Dąbrowo Górnicza & 8020,8 & 9260,4 & 9,6 & 8,5 & 9106,1 & 18 & 13 \\
\hline Gdańsk & 2983,6 & 2947,4 & 3,9 & 3,1 & 2939,2 & 1 & 4 \\
\hline Gdynia & 817,0 & 698,5 & 1,8 & 1,0 & 695,4 & 5 & 3 \\
\hline Katowice & 933,2 & 1167,2 & 2,6 & 0,8 & 1109,7 & 15 & 11 \\
\hline Kraków & 4246,1 & 4575,4 & 10,5 & 7,1 & 4548,3 & 6 & 2 \\
\hline Lublin & 829,9 & 595,2 & 2,1 & 0.8 & 591,8 & 0 & 2 \\
\hline Łódź & 2576,9 & 1663,1 & 6,2 & 3,4 & 1652,5 & 16 & 18 \\
\hline Opole & 558,3 & 543,3 & 0,7 & 0,8 & 539,3 & n.d. & n.d. \\
\hline Płock & 6441,4 & 5824,5 & 16,9 & 5,7 & 5799,0 & n.d. & 2 \\
\hline Poznań & 1689,1 & 1491,0 & 2,2 & 2,3 & 1485,1 & 8 & 11 \\
\hline Rybnik & 8600,8 & 7582,8 & 21,3 & 12,3 & 7521,1 & n.d. & n.d. \\
\hline Szczecin & 1138,3 & 1471,4 & 2,4 & 2,0 & 1466,7 & 15 & 6 \\
\hline Tarnów & 1307,9 & 1363,8 & 4,7 & 7,7 & 1349,5 & n.d. & 4 \\
\hline
\end{tabular}




\begin{tabular}{|c|c|c|c|c|c|c|c|}
\hline \multirow{4}{*}{ City } & \multicolumn{5}{|c|}{ Emission of gaseous pollution } & \multirow{3}{*}{\multicolumn{2}{|c|}{$\begin{array}{l}\text { Number of days with } \\
\text { exceeded target value } \\
\text { of ozone concentration }\end{array}$}} \\
\hline & \multicolumn{2}{|c|}{ total } & \multirow{2}{*}{$\begin{array}{l}\text { sulphur } \\
\text { dioxide }\end{array}$} & \multirow{2}{*}{$\begin{array}{c}\text { nitrogen } \\
\text { oxide }\end{array}$} & \multirow{2}{*}{$\begin{array}{l}\text { carbon } \\
\text { dioxide }\end{array}$} & & \\
\hline & 2010 & 2014 & & & & & \\
\hline & & & thousan & ones & & 2010 & 2014 \\
\hline Włocławek & 1069,4 & 1189,6 & 0,6 & 1,2 & 1182,5 & 9 & 13 \\
\hline Wrocław & 1255,0 & 1162,5 & 3,9 & 2,6 & 1154,6 & n.d. & n.d. \\
\hline Zielona Góra & 558,3 & 559,4 & 0,0 & 0,5 & 558,8 & 8 & 11 \\
\hline
\end{tabular}

Source: Authors' own elaborations based on data from the Central Statistical Office, GUS (2015).

Bearing in mind the synergistic impact on human health of high temperatures and simultaneous severe air pollution, the Polish cities made most vulnerable by transport and heavy industry are those located in the Upper Silesian agglomeration, but also Warsaw, Kraków and Łódź. It is in these areas that the most marked synergy between the two negative factors of pollution from transport and industry is to be observed. In turn, in the winter period, a third factor adding to those mentioned is municipal pollution from houses. It is ever more frequent for the result of this kind of activity to be a smog that is a tangible cause of lowered living standards for the inhabitants of cities. The health of the latter is harmed by such component elements as noxious chemical compounds, particulate matter (especially the tiny PM2.5 fraction) and high humidity, given that these encourage allergic reactions, can induce asthma and can lead to chronic bronchitis, respiratory impairment and higher incidences of certain types of cancer (Fig. 4).

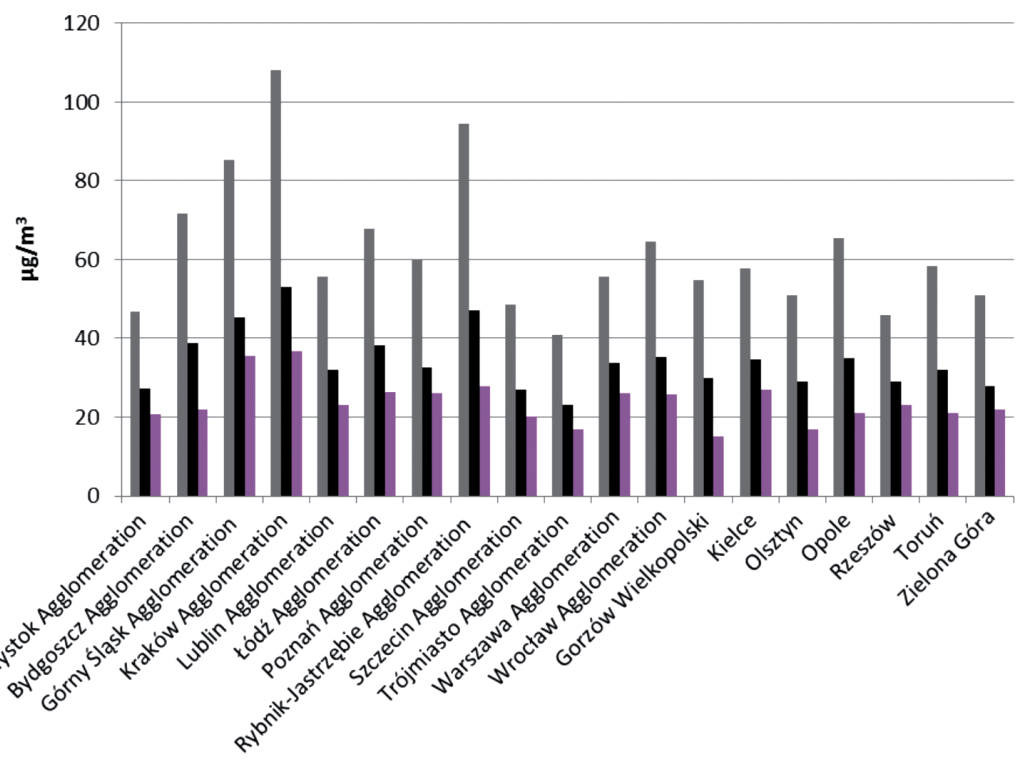

24-h concentration PM10 (value of standardized percentile S90.4 in $\mu \mathrm{g} / \mathrm{m}^{3}$ ) acceptable value: $50 \mu \mathrm{g} / \mathrm{m}^{3}$

- Annual mean concentration PM10 (value of standardized averange annual concentration in $\mu \mathrm{g} / \mathrm{m}^{3}$ ) - limit value: $40 \mu \mathrm{g} / \mathrm{m}^{3}$

- Annual mean concentration PM2,5 (value of standardized averange annual concentration in $\mu \mathrm{g} / \mathrm{m}^{3}$ ) - limit value: $25 \mu \mathrm{g} / \mathrm{m}^{3}$

Figure 4. Concentration of suspended particulate matter PM2.5 by agglomerations and cities in 2014 
People find it hard to spend time in urbanised areas in the summer months because of the combined (and mutually-augmentative) influences of high temperatures and air pollution (including rising concentrations of ozone). Indeed, time spent in a city in such circumstances may ensure the onset of a variety of respiratory and circulatory complaints, as well as dermatological conditions. In extreme cases, people may even die in such conditions. Thus, for example, this ultimate failure of the human organism to tolerate extreme heatwave conditions was what is estimated to have killed more than 100 people in the USA in 2011.

Research likewise confirms increased mortality when heatwaves develop in Poland. As was noted in the introduction, heatwaves in Warsaw have been associated with a statistically significant $16 \%$ increase in mortality rates (Kuchcik \& Degórski 2009). It can further be anticipated that the more polluted cities will experience higher death rates in heatwave conditions than those that are less polluted and have well-developed green infrastructure. There is thus an urgent need for planners to develop the spatial solutions and responses capable of easing the impacts of heatwave conditions on inhabitants, in line with fundamental principles that anthropopressure is to be minimised, and pro-environmental measures taken, wherever possible.

\section{Climate change and water shortages}

The World Water Council reports (drawn up in line with a proposal put forward at the 1977 Mar del Plata Conference of the United Nations) have since 1990 regarded Poland as one of the countries in deficit where the supply of water is concerned. Poland is in fact one of the least-blessed countries where water resources are concerned, there being $1600 \mathrm{~m}^{3}$ of water per inhabitant in an average year, and less than $1450 \mathrm{~m}^{3}$ in a dry year. This is less than half of the resources possessed by Spain, for example. Water resources are also decidedly scarcer than in next-door Germany - a country which attaches great importance to systems providing for the management of precipitation waters.

Thus very much indicated in the case of Poland, given these modest water resources, is the adoption of solutions seeking to achieve the maximum possible retention of water in the environment. If this is to happen there will need to be a revitalisation of natural bodies of water, in such a way that structures are installed to facilitate "natural" water retention. In addition, in urbanised areas, there is a need to rationalise the utilisation of precipitation waters within the overall wider context of urban water management. Different European states have in fact come up with a wide range of solutions and measures by which rainwater can be better managed, including:

- the construction of reservoirs, be these of the retention or retention/infiltration types,

- the utilisation of precipitation water, for example in the washing of cars or watering of gardens,

- "green roofs",

- the "loosening" of hard surfaces (draining pavements) and the greening of yards.

When rain falls on non-sealed surfaces, most of the water soaks straight down in to the soil, from which it percolates slowly downwards to feed into supplies of groundwater. Only around $20 \%$ of this water runs off across surfaces to reach watercourses directly. In contrast, city land that is paved and concreted over sees around $80 \%$ of precipitation water contribute to immediate surface runoff, which rapidly finds its way into drainage ditches and watercourses, often giving rise to local flash flooding, especially when a true downpour or cloudburst takes place. 
It needs to be emphasised that, just as flawed water management in urbanised areas can a cause of flooding, so it can equally well underpin shortfalls in the supply of water, especially during periods of drought. Given Poland's present hydrological circumstances, the problem of water shortage as further exacerbated by climate change can give rise to great difficulties with constancy of supply of water to our country's large urban agglomerations.

Warsaw is in fact involved in a series of projects promoting sustainable development principles and adaptation to climate. However, it remains difficult to persuade inhabitants to intercept and make use of rainwater, and to build houses or office blocks with a roof garden. Thankfully, this does not mean it is entirely impossible, as the building of the Warsaw University Library makes clear (Degórska 2014).

\section{Actions adapting cities to climate change, as exemplified by Warsaw}

In the view of the authors, the actions providing for mitigation or adaptation in the face of the negative impact of temperature increase in urban areas would be as follows:

- the preservation - within the spatial structure of the city - of areas that are not built up and thus capable of exerting an ameliorating influence on the processes heating up urban space, as well as limiting thermal stress through the facilitated movement of air;

- the preservation of extant areas of tall greenery, which allow for local-level lowering of temperature even in the immediate vicinity of buildings, thanks to the reduction in insolation that eases thermal stress in summer and help provide a respite for the bodies of sheltering inhabitants overburdened by heat;

- the introduction of open and tree-planted areas into districts slated for further intensive construction;

- the introduction of "green roofs" and "living walls" in areas with very high shares of contiguously built-up land, as well as activity to make good losses of green space associated with intensive construction;

- the raising of the energy efficiency of buildings;

- the lowering of the thermal conductivity of buildings through thermomodernisation, the modernisation of central-heating installations, insulation and the replacement of older windows;

- the installation of photovoltaic power stations on the roofs of public buildings;

- the ongoing modernisation of public-transport fleets;

- the preparation of urban infrastructure for the occurrence of higher windspeeds;

- the permanent monitoring of heat islands, and the establishment of a system providing the public with up-to-date information on the extent and severity of the phenomenon;

- the introduction of legal solutions and financial mechanisms by which buildings of public utility and dwellings alike can be fitted out with air conditioning units;

- the introduction of an early warning system in respect of enhanced risk of cardiological problems associated with heatwaves and the development of far-reaching urban heat island phenomena;

- the introduction of a system by which to assist the sick and elderly at the times of onset of heatwaves and the development of far-reaching urban heat island phenomena.

A further, very important issue to be resolved rapidly in the context of climate change entails enhanced efficiency of the system by which rain falling on the city is intercepted and utilised. The 
whole area of Warsaw in fact faces difficulties with the management and discharge of precipitation waters. The main tasks to be pursued in this regard concern:

- optimisation of discharge through redevelopment - and hence a raising of the efficiency - of the system of stormwater drainage;

- the fuller utilisation of areas of green space or otherwise planted with trees in the creation of a shield that delays and slows down the runoff of waters;

- the regeneration and remodelling of the system serving in the small-scale retention of water.

The last point, entailing the remodelling and further development of small bodies of water, offers the best means of protecting against flooding, whether this is due to torrential rain or flood crests passing along rivers. To this end, it would seem worthwhile to support and continue with work already done by the Warsaw districts to revitalise and reconstruct existing ponds and lakes. Furthermore, where the technical capabilities are present, efforts should be made to raise the natural water-retentiveness of areas most threatened by flooding, by way of the impoundment of water in drainage channels and bodies of water alike, with the attendant development of installations by which the system as a whole can be steered to retain maximal amounts of water in the environment, rather than facilitate the runoff that causes land to be inundated abruptly from outside or beneath.

The issues of the interception and discharge of precipitation waters within Warsaw are very complex, given that receiving waters take the form of small streams, brooks, ditches or canals that are often present on private land, are put at risk should the runoff of water be much accelerated at times of heavy rainfall, are subject to reduced throughputs in periods with precipitation shortages (on account of the sealing of many surfaces within the urban parts of many drainage basins and the consequently reduced alimentation of groundwater) and are also markedly polluted. Furthermore, what remains of the system of designated drainage channels, still controlling the outflow of precipitation water, is mostly located on private land, and is supposed to be kept in the appropriate technical state by the owner. Enforcing this kind of obligation is obviously a problem, and in many places the drainage systems present previously have been ruined, or covered over altogether, with consequent disruption of water relations in the given areas.

\section{Summary and conclusions}

The threat to the functioning of the city system resulting from climate change requires a series of adaptive actions. In Poland, these are currently at the stage where strategic documents are being drawn up to adapt cities to the climate change presented in global and regional climate scenarios. However, it needs to be stressed that the strategic studies and planning documents that have come into being so far take only limited account of current knowledge on assumed climate change, or the nature of this change for the quality of human life. A notable positive exception would be the action being or to be taken to limit emissions of greenhouse gases.

The spatial studies done for Warsaw cited in this work and concerning possible changes of climate advocate a great deal of action intended to raise living standards of inhabitants, increase their security, lower the city's operating costs and optimise structural and spatial solutions where development is concerned. Assessing the variant solutions when it comes to adaptation, and coming up with a ranking of different associated actions, one must note that the key undertakings are those seeking to limit city temperature increases that lead to the emergence of so-called urban heat island (UHI) phenomena. While it is true that these cannot be precluded altogether, they can be modified in 
terms of intensity, if appropriate planning action is taken at city level and more locally. Appropriate planning can also facilitate inhabitants' adaptation to the phenomenon as and when it does arise.

The state of our knowledge to date confirms the significant influence land management can have on the intensity of UHI, when housing estates are compared from the point of view of their shares of biologically active land. Of slightly lesser importance is the indicator of the degree to which an area is built up - i.e. as a function of distance from city-centre areas. The conclusion is therefore that the extent of the biologically active area plays a key role as housing estates are designed - to limit the extent and intensity of the UHI affect as far as possible. Work done to date suggests that this effect can only be achieved where no less than $45-50 \%$ of a given area remains biologically active, and thus not built up. However, the determination of a precise threshold value requires further analyses in a greater number of model areas that take into consideration the form of construction and land cover, including also the share of the area not built up that is beyond the biologically active land as defined traditionally.

A further very important activity in terms of adaptation is flood protection in urbanised areas, and notably the development of a flood-prevention scheme and system. There is obviously no way of introducing an entirely safe system of protection against flooding that is foolproof, and can ensure $100 \%$ protection no matter how high the flood crest. However, systems of this kind can limit damage as far as possible, as and when flood events arise. It needs to be recalled here that flood damage goes beyond losses of property to include the negative consequences for the human psyche of going through one major flood event and/or fearing the arrival of another.

One aspect to flood-protection prophylaxis is the construction of specialist infrastructure including flood banks. However, embankments are ultimately just earthworks, and ones that are perpetually in need of maintenance. Furthermore, their existence of necessity goes hand in hand with the pursuit of other hydrotechnical measures. In many Polish cities, and not least Warsaw, the approach denotes a raising of the level of banks along some sections if standards are to be increased to first class. But attention also clearly needs to be paid to the area between the flood banks, to ensure that this is sufficiently clear to allow for easy runoff of floodwaters, most especially those associated with cresting events capable of being generated by the torrential rain and cloudbursts that cause flash flooding.

Also referred to in this paper is the effort to address the threat of water shortages through further adaptational action helping to maintain the proper functioning of a city in circumstances of climate change. The concrete examples suggests that Warsaw is in a favourable position where the supply of water to its inhabitants is concerned, given that it has two independent sources in the Zegrze Reservoir and the River Vistula. However, no matter what its everyday situation as regards abstraction may be, each city ought to have an emergency water-supply system that can feed into water pipelines and supply citizens with drinking water in the circumstances of protracted drought. Thanks to a suitable location as regards artesian deposits of water from the Oligocene, Warsaw does in fact possess a resource that can always serve as an additional water source for city inhabitants.

In summing up the analysis carried out, it is necessary to make clear that the spatial development of cities entails many threats and problems only exacerbated by climate change, with the result that it becomes essential to take action to adapt to this more fully. Key activity will include efforts to limit further rises of temperature in city interiors and to optimise water management. In each case, the overriding objective must be the safety and security of city-dwellers from the point of view of their resistance to climate change. While an ageing society and worsening hydrological and thermal conditions seem an unfortunate combination, they can also serve as a the stimulus to the develop- 
ment of the proposed spatial solutions, in line with which the human being is seen as the key object underpinning concrete and relevant action.

\section{References}

Błażejczyk K., Kuchcik M., Milewski P., Dudek W., Kręcisz B., Szmyd J., Degórska B., Pałczyński C., 2014. Miejska wyspa ciepła w Warszawie, uwarunkowania klimatyczne i urbanistyczne. Warszawa: IGiPZ PAN, SEDNO Wydawnictwo Akademickie, 171 pp.

Degorska B., 2007. Key problems in the relation between the environment and spatial development in Poland. [in:] T. Marszał (ed.), European Spatial Research and Policy, vol. 14, no. 2, pp. 54-89.

Degórska B., 2014, Sensibility and adaptation big cities to climate change in the context of rising air temperature. National Spatial Planning Committee, Biuletyn KPZK PAN 254, pp. 27-46.

EEA 2012. Urban adaptation to climate change in Europe, Challenges and opportunities for cities together with supportive national and European policies. EEA Report 2, 2012, European Environment Agency, 143 pp.

Fischer E. M., Schar C., 2010. Consistent geographical patterns of changes in high-impactEuropean heatwaves. Nature Geoscience, vol. 3, no. 6, pp. 398-403.

Greiving S., 2011. Climate change and territorial effects on regions and local economies. ESPON Climate. ESPON \& IRPUD, TU Dortmund, 55 pp.

IPCC 2007. Climate Change, Synthesis Report. IPCC, Geneva, Switzerland. 104 pp.

Kuchcik M., Degórski M., 2009. Heat and cold related mortality in the north-east of Poland as an example of the socio-economic effects of extreme hydrometeorological events in the Polish Lowland. Geographia Polonica, vol. 82, no. 1, pp. 69-78.

Raport Polska 2011. Gospodarka Społeczeństwo Regiony. Ministerstwo Rozwoju Regionalnego, Warszawa.http://www.mrr.gov.pl/rozwoj_regionalny/Ewaluacja_i_analizy/Raporty_o_rozwoju/ Raporty_krajowe/Documents/Raport_Polska_2011.pdf za OECD Urban Policy Reviews, Poland 2011. OECD Publishing [11 September 2015].

WMO, 2013. The global climate 2001-2010. A decade of climate extremes. Summary Report, WMO-No. 1119, Geneva, 15 pp.

UN, 2007. World population growth will occur in urban areas of world. POP/757, New York: United Nations Report States, 198 pp. 


\section{ALL VOLUMES OF EUROPA XXI}

28 (2015) : Road corridors in the natural,social and economic environment 27 (2014) : Territorial capital in practice - environmental and social issues 26 (2014) : The role of territorial capital in development polices 25 (2014) : Detecting Territorial Potentials and Challenges 24 (2013) : Transport accessibility at regional scale in Europe 23 (2013) : Services of General Interest in European Union 22 (2012) : Territorial development and cohesion in a multi-scalar perspective 21 (2010) : Environmental and infrastructural networks

20 (2010) : European Union: external and internal borders, interactions and networks

19 (2009) : European urban system: metropolization and networking 18 (2008) : Territorial dilemmas of socio-economic development in Europe

17 (2008) : New functions of rural and industrial space in Central and Eastern Europe

16 (2007) : Regional development in Central Europe - cohesion or competitiveness

15 (2006) : Regional periphery in Central and Eastern Europe 14 (2006) : Core and peripheral regions in Central and Eastern Europe 13 (2005) : New spatial relations in new Europe 12 (2005) : Central and Eastern Europe: changing spatial patterns of human activity

11 (2004) : Przestrzeń Europy. Przestrzeń Unii Europejskiej

10 (2003) : Society and environment. Towns and settlement in Europe

9 (2003) : Polska i Europa: kształtowanie przestrzeni wolności

8 (2003) : European space in the face of enlargement: the West to East European Trajectory project

7 (2002) : Slovakia and Poland: urban, social and demographic questions, relations between neighbours

6 (2001) : Integracja europejska - dylematy spójności i konwergencji regionalnej

5 (2000) : Przestrzeń ekologiczna Polski. Dekolektywizacja rolnictwa i sytuacja zdrowotna w Europie Środkowej, Wschodniej i Południowo-Wschodniej

4 (2000) : Powiązania handlowe Polski z Europą. Z debaty

o przyszłym kształcie zjednoczonej Europy

3 (1999) : Obszary szczególnej troski i nowych możliwości rozwoju na przykładzie Polski i Ukrainy

2 (1998) : Przestrzeń Europy Środkowej - przykłady transformacji

1 (1998) : Sieć komunikacyjna Polski w europejskich procesach integracyjnych 


\section{The impact of climate on some sectors of the economy in Poland and Bulgaria and their adaptation}

- Magdalena Kuchcik

The present and future state of the climate in Poland and Bulgaria

- Valentin Kazandjiev, Marek Degorski, Krzysztof Błażejczyk, Veska Georgieva

Agroclimatic conditions in Bulgaria and agricultural adaptation

- Veska Georgieva, Valentin Kazandjiev, Marek Degorski, Krzysztof Błażejczyk, Magda Kuchcik, Bożena Degorska Investigation on the soil moisture reserves and

meteorological conditions in relation to basic soil types in Bulgaria

- Krzysztof Błażejczyk, Valentin Kazandjiev, Marek Degórski, Peter Dimitrov

Assessment of occupational heat stress risk among agriculture workers in Poland and Bulgaria

- Paweł Milewski, Jakub Szmyd

Biothermal contrasts while travelling in or between Poland and Bulgaria

- Jakub Szmyd, Paweł Milewski

Daily amplitude of air temperature in Poland and Bulgaria a comparative study

- Bożena Degórska, Marek Degórski

The process of the spatial development of large cities in Poland and its adaptation to climate change: opportunities and threats 